\title{
Transcriptome-wide measurement of mRNA polyadenylation state
}

\author{
Traude H. Beilharz ${ }^{\mathrm{a}, \mathrm{b}, 1}$, Thomas Preiss ${ }^{\mathrm{a}, \mathrm{b}, \mathrm{c}, \mathrm{,}}$ \\ a Molecular Genetics Division, Victor Chang Cardiac Research Institute (VCCRI), Lowy Packer Building, 405 Liverpool Street, Darlinghurst (Sydney), NSW 2010, Australia \\ ${ }^{\mathrm{b}}$ St Vincent's Clinical School, University of New South Wales, Sydney, NSW 2052, Australia \\ 'School of Biotechnology E'Biomolecular Sciences, University of New South Wales, Sydney, NSW 2052, Australia
}

\section{A R T I C L E I N F O}

Article history:

Accepted 9 February 2009

Available online 20 February 2009

\section{Keywords:}

$\operatorname{Poly}(A)$ tail

Polyadenylation

Deadenylation

Translational control

mRNA decay

Post-transcriptional regulation

Polysome

Microarray

Transcriptome

Proteome

\begin{abstract}
A B S T R A C T
The 3' poly(A) tail has important roles throughout the eukaryotic mRNA life cycle. A characteristic aspect of poly $(A)$ tail function is furthermore that it can be modulated by changes in its length. This is in turn a wellrecognised cellular means to regulate both, mRNA translation and stability, and a positive correlation has often been found between the efficiency of mRNA translation and the length of its poly(A) tail. Here we describe methodology to measure mRNA polyadenylation state in a transcriptome-wide manner, using separation of cellular mRNA populations on $\operatorname{poly}(\mathrm{U})$ sepharose in combination with microarray analysis of the resulting fractions. We further detail methods for bulk and mRNA-specific poly(A) tail length measurements to monitor the efficiency of initial mRNA separation and to verify candidates selected from the microarray data. Although detailed here for the study of yeast mRNAs, these methods are adaptable to the investigation of any cellular context in which poly(A) tail length control is known or suspected to operate.
\end{abstract}

(c) 2009 Elsevier Inc. All rights reserved.

\section{Introduction}

All nuclear-encoded eukaryotic mRNAs exhibit a $5^{\prime}$ $\mathrm{m}^{7} \mathrm{G}\left(5^{\prime}\right) \operatorname{ppp}\left(5^{\prime}\right) \mathrm{N}$ cap structure and with few exceptions, also a $3^{\prime}$ poly(A) tail. Both, cap and tail are known to influence mRNA splicing, transport, translation, and stability. In particular, the processes of mRNA translation and canonical decay both require access to these two mRNA end modifications [1]. Canonical mRNA decay starts by poly(A) tail shortening, followed by decapping and exonucleolytic degradation [2]. Conversely, efficient initiation of translation depends on the formation of a closed-loop conformation of the mRNA involving the cap and tail as well as their cognate binding proteins [3-5]. Control of translation is frequently achieved through an interference with the formation of this closed-loop [6]. The poly(A) tail is of particular interest, as dynamic variations in its length afford a tuneable mode of mRNA-specific control. microRNAs employ this type of regulation [7-11] and it has long been studied using the case of 'stock-piled' maternal mRNAs in Xenopus oocytes. These mRNAs are stored in an under-adenylated form in arrested oocytes, but they become re-adenylated and

\footnotetext{
* Corresponding author. Address: Molecular Genetics Division, Victor Chang Cardiac Research Institute (VCCRI), Lowy Packer Building, 405 Liverpool Street, Darlinghurst (Sydney), NSW 2010, Australia. Fax: +61 292958601.

E-mail addresses: t.beilharz@victorchang.edu.au (T.H. Beilharz), t.preiss@victorchang.edu.au (T. Preiss).

1 Fax: +61 292958601
}

translationally active during oocyte maturation and early embryonic divisions [12-14]. Numerous similar examples have further documented a positive correlation between the efficiency of mRNA $\operatorname{poly}(\mathrm{A})$ tail length and translation efficiency.

The $\operatorname{poly}(A)$ tail length is thus a surrogate parameter through which to assess the functional state of an mRNA, rather like the measurement of its polysome association by density gradient ultracentrifugation. A combination of this classic method of translational control research with microarray analysis, referred to as translation state array analysis (TSAA) has been developed and successfully applied to many cellular conditions $[15,16]$. We have employed the TSAA approach in previous work [17] and as an extension of this work we devised a method, termed polyadenylation state array (PASTA) analysis, which combines separation of cellular mRNA on $\operatorname{poly}(U)$ sepharose with subsequent microarray analysis. We probed the transcriptomes of $S$. cerevisiae and $S$. pombe with the PASTA methodology and found a widespread correlation between poly(A) tail length and translation in both cases, as well as several other global co-regulatory tendencies $[18,19]$.

Here we detail our method for the fractionation of cellular mRNA based on poly(A) tail length using step-wise thermal elution from a poly $(U)_{100}$ sepharose matrix and describe some approaches to the microarray analysis of the resulting fractions. We further provide protocols for bulk and mRNA-specific poly(A) tail length measurements, as they are required for control and verification purposes. 


\section{Description of method}

\subsection{Overview}

We isolate total yeast RNA by the hot acid phenol method and bind it to poly $(U)_{100}$ sepharose beads in suspension. This is done by heat-denaturing an aliquot of RNA in the presence of poly $(U)_{100}$ sepharose, followed by cooling to anneal poly(A) tails to poly(U) tracts on the beads. Following washes at low temperature, RNA is batch-eluted from the beads by step-wise increases in temperature (Fig. 1). To test fractions for the degree of tail length separation, aliquots of the eluted RNA are labelled at the $3^{\prime}$ end with $\alpha-\left[{ }^{32} \mathrm{P}\right] \mathrm{pCp}$ followed by digestion of the mRNA body with RNases T1 and A. This leaves only poly(A) tracts intact, which can be resolved by denaturing PAGE (Fig. 2A). The RT-PCR-based Ligation-mediated Poly(A)-Test (LM-PAT) is a sensitive assay yielding product sizes that reflect the $\operatorname{poly}(\mathrm{A})$ tail lengths present on a spe-
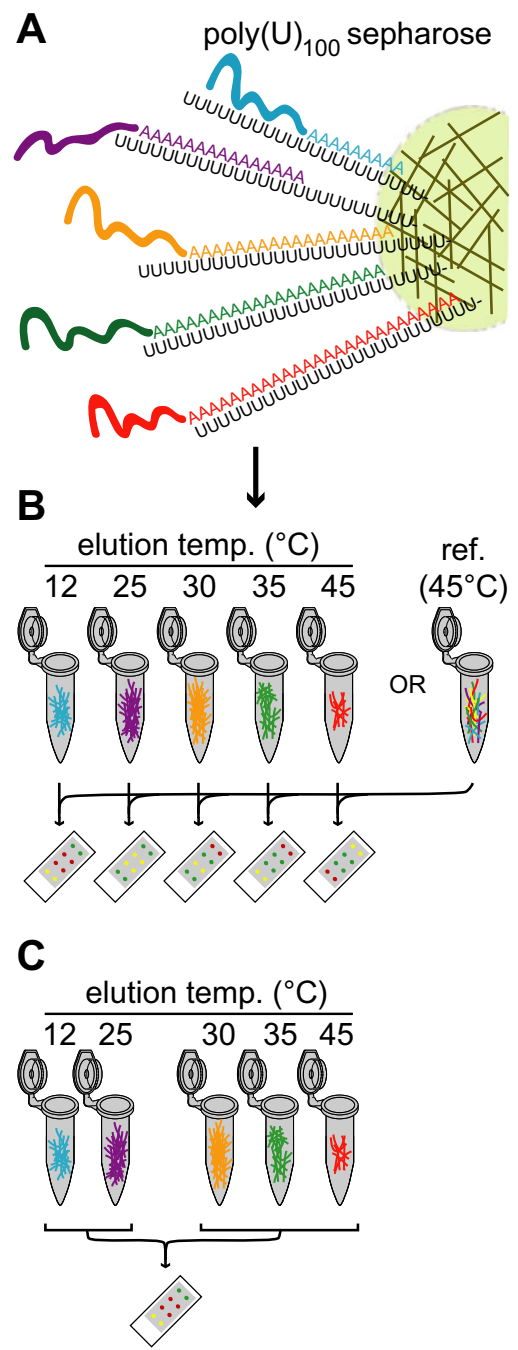

Fig. 1. PolyAdenylation STate Array (PASTA) analysis. (A) mRNA is bound to $\operatorname{poly}(\mathrm{U})_{100}$ sepharose beads at $12{ }^{\circ} \mathrm{C}$ and then eluted by step-wise increases in temperature as detailed in the main text. (B) For high-resolution PASTA analyses, each temperature eluate (e.g., reverse-transcribed into Cy5-labeled cDNA) is compared against reference mRNA eluted in a single step at $45^{\circ} \mathrm{C}$ (e.g., as Cy3labeled cDNA) on separate dual-colour microarrays. (C) For low-resolution PASTA analyses, pools of elution fractions were compared to each other by microarray $\left(30^{\circ} \mathrm{C}, 35^{\circ} \mathrm{C}\right.$, and $45^{\circ} \mathrm{C}$ [e.g., Cy5-labeled cDNA] versus $12^{\circ} \mathrm{C}$ and $25^{\circ} \mathrm{C}$ [e.g., Cy3labeled cDNA]). (A) Reproduced with permission, RNA 13: 982-997 (c) 2007 by the RNA society. (B) \& (C) Reproduced with permission, Microbiology Australia 28: 8586 (c) The Australian Society for Microbiology Inc. cific mRNA (see schematic in Fig. 2B). It can be used to monitor the efficacy of the poly $(U)$ chromatography step (Fig. $2 \mathrm{C}$ ) as well as to verify tail lengths on candidate mRNAs. These candidates are selected from dual-colour microarray data that are generated by either comparing each poly(U) sepharose eluate separately against a common reference (in a high resolution approach depicted in Fig. 1B), or by combining fractions into a low temperature and a high temperature eluate pool, which are directly compared with each other (in a pool comparison approach depicted in Fig. 1C). Several strategies may be used to rank or otherwise select mRNA candidates based on the microarray-generated measure of their polyadenylation state (Fig. 3 ).

\subsection{Step-by-step protocols}

\subsubsection{Preparation of total RNA from yeast}

Total RNA of high quality and purity is required so that it remains intact throughout the lengthy manipulations at elevated temperature. It can be rapidly prepared from yeast cells according to the hot acid phenol method. There are several versions of this method in use that differ in subtle ways from the original [20]. The protocol we use is based on that of the Derisi laboratory (http://cat.ucsf.edu/pdfs/TotalRNAIsolation.pdf), with modifications as described below. Total RNA prepared by other methods or from other sources should also be suitable, as long as it is high quality. All solutions are prepared from RNase-free stocks in new or RNase-free plastic or glassware.

1. A yeast overnight culture is diluted $1 / 50$ into $50 \mathrm{ml}$ of fresh media and re-grown for at least 3 generation times to an $\mathrm{OD}_{600 \mathrm{~nm}}$ between 0.5 and 0.8 .

2. Transfer cells to a $50 \mathrm{ml}$ Falcon tube, and collect cells by centrifugation (cooled bench-top clinical centrifuge at $3000 \mathrm{~g}$ for $3 \mathrm{~min}$ ), then resuspend once in $50 \mathrm{ml}$ ice-cold $\mathrm{dH}_{2} \mathrm{O}$ and spin cell down again.

3. Remove supernatant, resuspend pellet in $1 \mathrm{ml}$ ice-cold $\mathrm{dH}_{2} 0$ and transfer to a $2 \mathrm{ml}$ screw cap microfuge tube (which helps to prevents phenol leaks, see below). Spin again for $30 \mathrm{~s}$ at $10,000 \mathrm{~g}$ in a cooled microcentrifuge and discard supernatant. At this point the cell pellet can be frozen in liquid nitrogen and stored at $-80^{\circ} \mathrm{C}$.

4. Resuspend the cell pellet on ice in $400 \mu \mathrm{l} \mathrm{AE}$ Buffer ( $50 \mathrm{mM}$ sodium acetate $\mathrm{pH} 5.2,10 \mathrm{mM}$ EDTA). Add $33 \mu \mathrm{l}$ of $25 \%(\mathrm{w} / \mathrm{v})$ SDS and $400 \mu \mathrm{l}$ acid phenol (Invitrogen Cat \# 15594-047), vortex and transfer to a water-bath at $65^{\circ} \mathrm{C}$. Incubate at $65^{\circ} \mathrm{C}$ for $20 \mathrm{~min}$ with intermittent vortexing, making sure that the phases remain thoroughly mixed. At this temperature there should be no distinction between phases.

5. Transfer microfuge tube to ice and incubate for $5 \mathrm{~min}$ to precipitate SDS. Spin at $16,000 \mathrm{~g}$ in a cooled bench-top microcentrifuge.

6. Transfer the supernatant (both phases) into a fresh $2 \mathrm{ml}$ microfuge tube and add $400 \mu \mathrm{l}$ chloroform. Vortex thoroughly and spin at $16,000 \mathrm{~g}$ in a microcentrifuge for $5 \mathrm{~min}$ at room temperature.

7. Remove the aqueous phase to a fresh $1.5 \mathrm{ml}$ microfuge tube, avoiding the inter-phase and re-extract with an equal volume of chloroform:isoamylacohol $(24: 1, \mathrm{v} / \mathrm{v}$; Fluka Cat \# 2566).

8. Transfer aqueous phase to a new microfuge tube containing $1 / 10$ th vol of $5 \mathrm{M} \mathrm{NaCl}$ and add an equal volume of isopropanol. Mix by inversion, then spin for $10 \mathrm{~min}$ at $16,000 \mathrm{~g}$ in a microcentifuge at room temperature. A white pellet should be clearly visible at this stage. Wash the pellet with $80 \%$ ethanol, remove all traces of solvent and dry pellet at room temperature. 


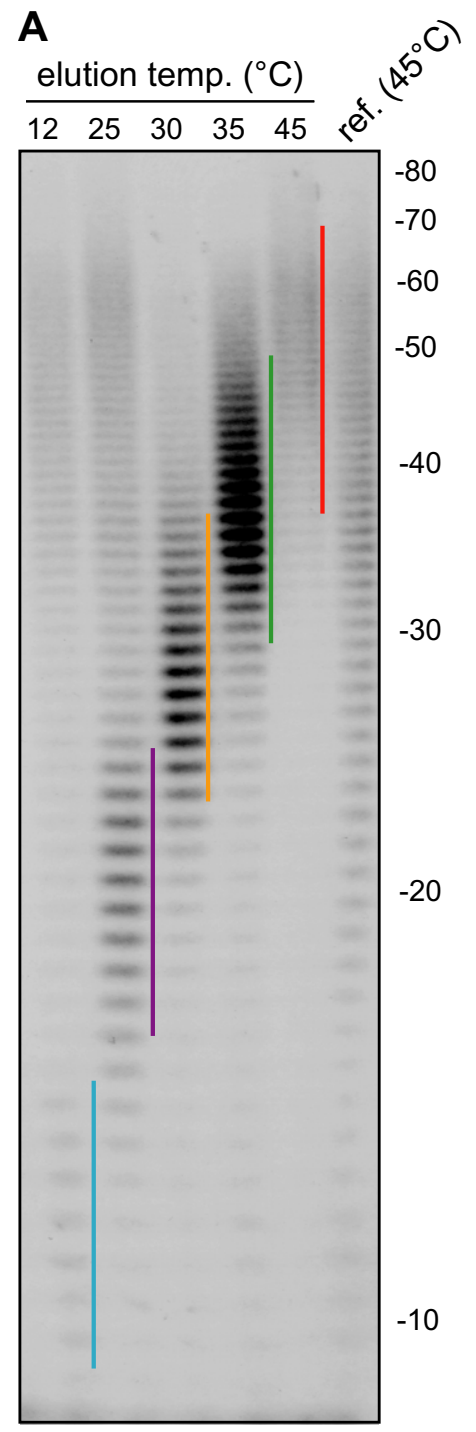

B
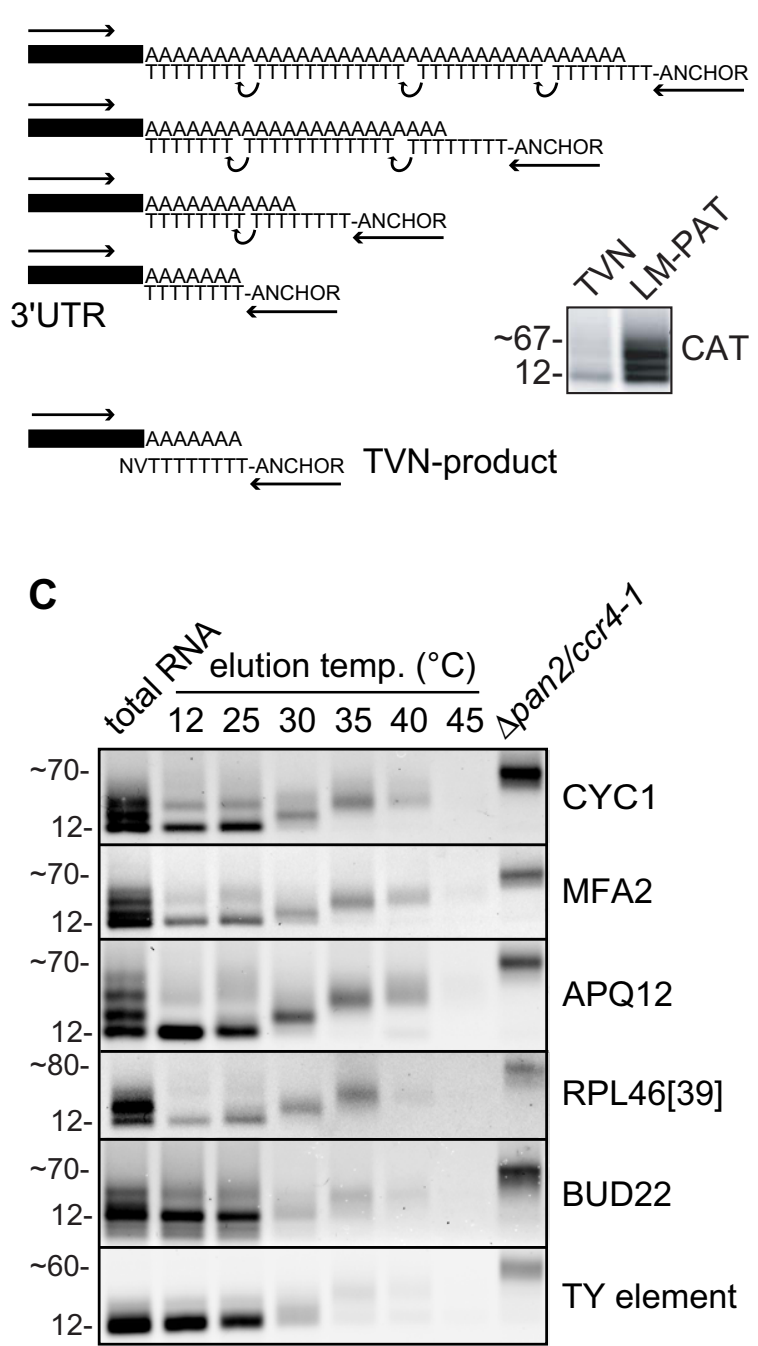

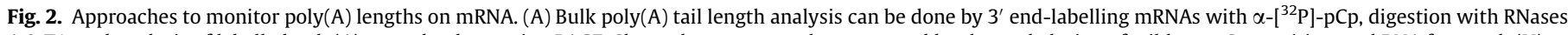

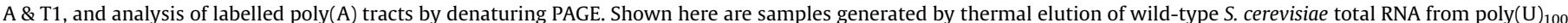

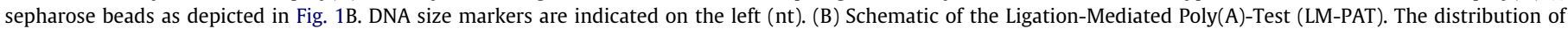

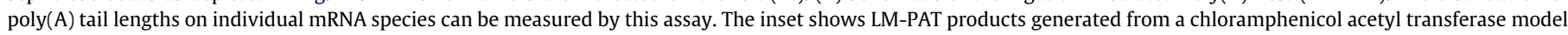

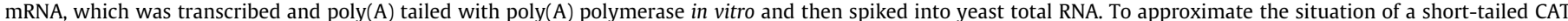

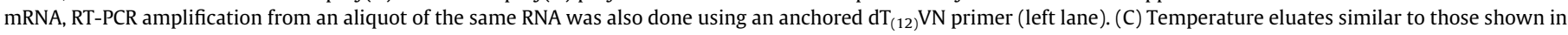

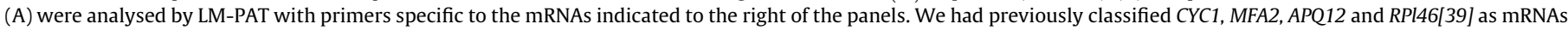

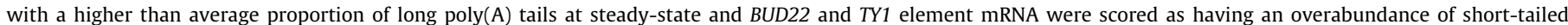

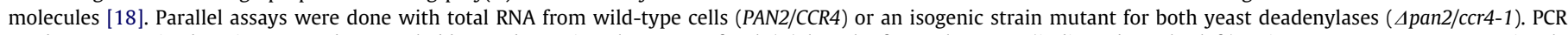

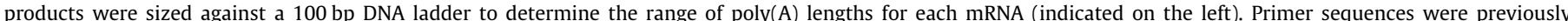

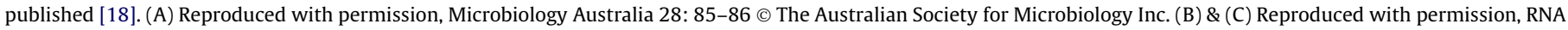
13: $982-997$ (C) 2007 by the RNA society.

9. Resuspend in $\sim 50 \mu \mathrm{l}$ RNase-free $\mathrm{dH}_{2} 0$, more or less depending on the number of cells in the starting material. The resulting RNA should have $\mathrm{OD}_{260 \mathrm{~nm}} / \mathrm{OD}_{280 \mathrm{~nm}}$ and $\mathrm{OD}_{260 \mathrm{~nm}} / \mathrm{OD}_{230 \mathrm{~nm}}$ ratios of $>2$.

10. To visualize the RNA, prepare a $1 \%$ agarose minigel in $1 \times$ TAE containing $10 \mu \mathrm{g} / \mathrm{ml}$ ethidium bromide. Make a $2 \times$ RNA loading dye by adding a $4 \mu \mathrm{l} 250 \times$ concentrated stock of bromophenol blue and xylene cyanol to $1 \mathrm{ml}$ $100 \%$ formamide (Sigma-Aldrich Cat \# F9037). Denature $1 \mu \mathrm{g}$ RNA in a total of $10 \mu \mathrm{l}$ loading dye at $80^{\circ} \mathrm{C}$ for $5 \mathrm{~min}$. Run the gel until the bromophenol blue dye has migrated no more than 1/3rd way down the gel. Running the gel too far results in smearing due to RNA refolding.

\subsection{2. $\operatorname{Poly}(U)$ chromatography}

Binding to $\operatorname{poly}(\mathrm{U})$ sepharose at low temperature, followed by step-wise thermal elution can be used to fractionate cellular mRNAs by the length of their poly(A) tail (Fig. 1) [21,22]. In our work $[18,19]$, we have employed a sepharose matrix that is coupled to $\operatorname{poly}(\mathrm{U})_{100}$ ligands, which is well suited to the fractionation of yeast mRNAs, as their poly(A) tail lengths do not exceed $\sim 70-90$ adenosines. Instead of more elaborate set-ups such as a thermostated, jacketed chromatography column, we have opted for a simple approach of batch binding to beads in suspension and collection of beads by centrifugation, which uses equipment that is readily available in a molecular biology research environment. Much of our methodology is based on that described by Binder et al. [21] and the product specifications that are supplied with 
the poly $(U)_{100}$ sepharose 4B (GE Healthcare Cat \# 17-0610-01). We use an Eppendorf Thermomixer Compact to suspend and incubate beads at various temperatures. Centrifugation steps are performed in either ambient temperature $\left(23^{\circ} \mathrm{C}\right)$ or cooled $\left(4^{\circ} \mathrm{C}\right)$ Eppendorf bench-top microcentrifuges (models $5415 \mathrm{D}$ and $5415 \mathrm{R}$, respectively). All buffers are prepared from RNase-free stock solutions. The protocol detailed below is the result of a series of systematic optimisations of buffer composition, as well as incubation times and temperatures until satisfactory results were achieved. It should be possible to change the type of beads, length of poly $(U)$ ligand, or the source RNA material used, but this will require retuning of said experiment parameters.

A

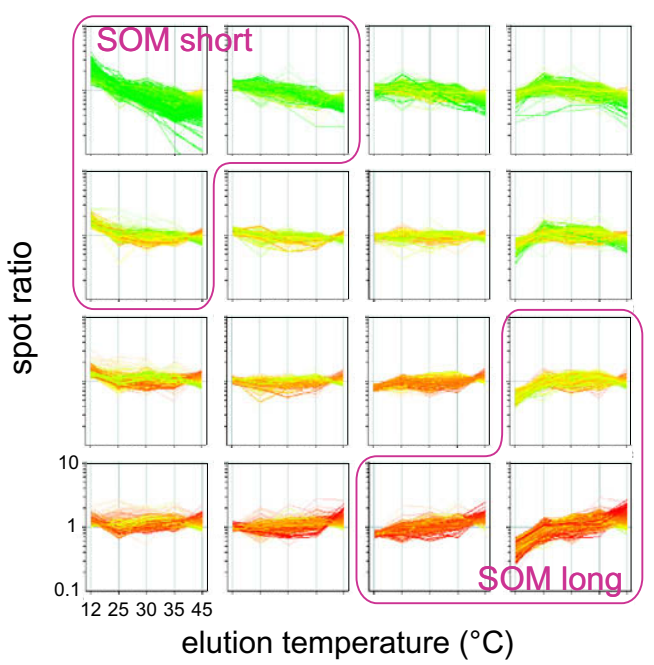

B
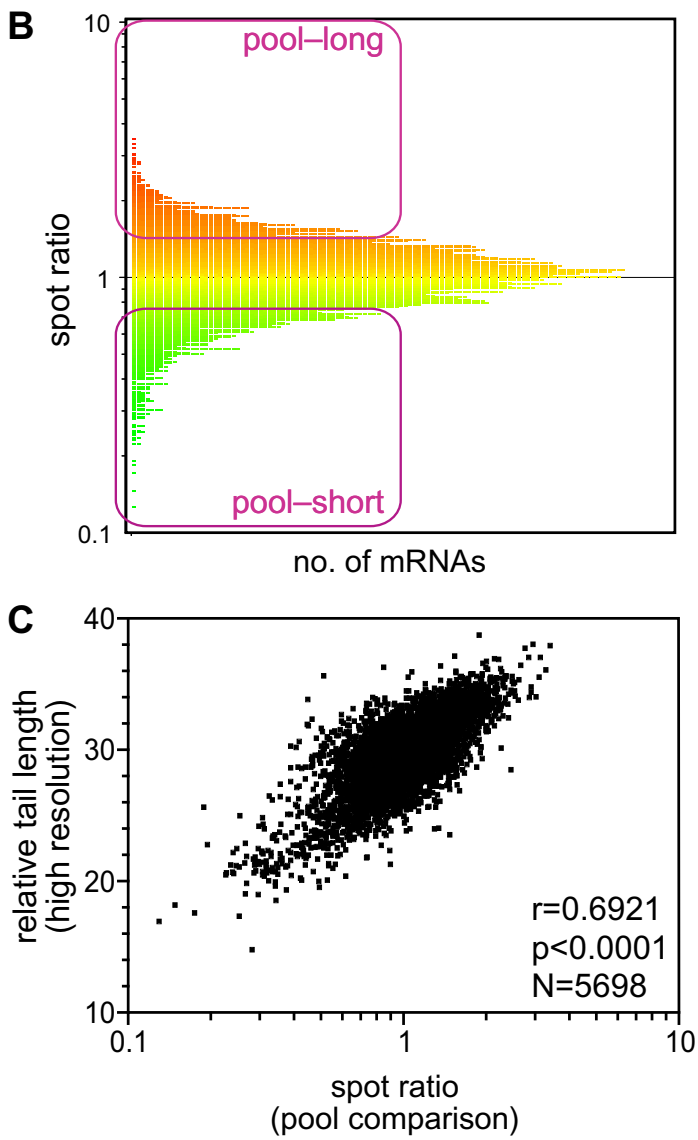

1. Suspend $\sim 500 \mathrm{mg}$ of dry poly $(\mathrm{U})_{100}$ sepharose in $10 \mathrm{ml}$ of Hydration Buffer (HB; $0.1 \mathrm{M} \mathrm{NaCl} ; 10 \mathrm{mM}$ Tris- $\mathrm{HCl}$ at $\mathrm{pH} 7.4$ ) at room temperature. Hydration should be performed for at least $30 \mathrm{~min}$ at room temperature or overnight at $4{ }^{\circ} \mathrm{C}$. Prior to use wash a further three times in $10 \mathrm{ml} \mathrm{HB}$, each time collecting the beads by spinning at $500 \mathrm{~g}$ for $5 \mathrm{~min}$ in a bench-top clinical centrifuge.

2. Transfer the equivalent of $150 \mu$ of settled wet gel volume per binding/elution reaction to a new $1.5 \mathrm{ml}$ microfuge tube and wash once with $1 \mathrm{ml}$ of Elution Buffer (EB; $0.1 \mathrm{M} \mathrm{NaCl}, 0.01 \mathrm{M}$ EDTA, 0.5 M Tris- $\mathrm{HCl}$ at pH 7.4, 0.2\% SDS, 25\% molecular biology grade formamide; Sigma-Aldrich Cat \# F9037), followed by High-Salt Binding Buffer (HSBB; $0.7 \mathrm{M} \mathrm{NaCl}, 0.01 \mathrm{M}$ EDTA, $0.5 \mathrm{M}$ Tris- $\mathrm{HCl}$ at $\mathrm{pH} 7.4,0.2 \%$ lauryl sarcosine, formamide), each for $5 \mathrm{~min}$ at $70^{\circ} \mathrm{C}$. For all wash and elution steps, sediment matrix by spinning at $5000 \mathrm{~g}$ for $30 \mathrm{~s}$. We use disposable insulin syringes (Becton Dickinson Cat \# 326719) to remove as much liquid as possible from the matrix at buffer change and elution steps without loss of the matrix.

3. Add $600 \mu \mathrm{l}$ of HSBB and up to $150 \mu \mathrm{g}$ of total yeast RNA to the prepared poly $(U)_{100}$ matrix. Denature the RNA in the presence of beads for $5 \mathrm{~min}$ at $70^{\circ} \mathrm{C}$ in a dry heating block.

4. Subsequent binding and wash steps are performed in the thermomixer (set to $1100 \mathrm{rpm}$ ) in a cold room. Transfer the microfuge tube to the thermomixer set at $55^{\circ} \mathrm{C}$, then change setting to $12^{\circ} \mathrm{C}$ and leave for $90 \mathrm{~min}$ ( $\sim 25 \mathrm{~min}$ of ramp-down time and $\sim 65$ min incubation at $12^{\circ} \mathrm{C}$ ).

5. After binding, the matrix is washed four times by addition of $1 \mathrm{ml}$ ice-cold HSBB and incubation at $12^{\circ} \mathrm{C}$ for $5 \mathrm{~min}$ in the thermomixer. Between wash steps the matrix is collected by centrifugation as in step 2 above.

6. Each thermal elution step is performed by resuspending the matrix in $600 \mu \mathrm{l} \mathrm{EB}$ at the specified temperature for $5 \mathrm{~min}$. We found that elution steps at $12,25,30,35,45^{\circ} \mathrm{C}$ work well to achieve a good size separation between fractions. (Ideally, the higher temperature elution steps are carried out in a second thermomixer placed at room temperature. Transferring the first one from the cold room to a lab bench and reconnecting it immediately might risk electrical faults due to condensation.)

7. Each elution fraction is transferred to a new $1.5 \mathrm{ml}$ microfuge tube and re-spun. $550 \mu \mathrm{l}$ of the fraction is then transferred (avoiding any carryover of beads) to a $2 \mathrm{ml}$ microfuge tube containing $1 / 10$ vol of $5 \mathrm{M} \mathrm{NaCl}$ and Pellet Paint co-precipitant (Novagen Cat \# 69049-4). The microfuge tubes are then filled with ice-cold ethanol $(\sim 1.4 \mathrm{ml})$ and stored at $-80^{\circ} \mathrm{C}$ for at least

Fig. 3. Selection of candidate mRNAs from PASTA data. (A) To select candidates from high-resolution PASTA data, mRNA elution profiles may be sorted into bins based on profile shape. Shown here is a $4 \times 4$ matrix of such bins, applying a selforganising-map (SOM) algorithm to our published S. cerevisiae data [18]. Profiles are coloured by array spot ratio for the $45^{\circ} \mathrm{C}$ elution. mRNAs in the adjacent profile classes on the top left are candidates for a high proportion of short-tailed molecules (SOM-short). Profile classes on the bottom right represent candidate mRNAs with a high proportion of long-tailed mRNA molecules (SOM-long, both outlined in purple). (B) For low-resolution PASTA data [18], a fold-change cut-off can be chosen to generate mRNA groupings for further analysis (pool-short or pool-long, outlined in purple). (C) To generate a relative value of poly(A) tail length from the high-resolution PASTA data, ratios of each mRNA from the 5 elution fractions can be transformed into percentages of mRNA for each fraction. The percentage of each fraction was multiplied by arbitrary weights of $0.1,0.2,0.3,0.4$ and 0.5 for the respective fractions $1-5$ and summated, so that all mRNAs receive a relative poly(A) tail length measure between 10 and 50 [arbitrary units; [19]]. The graph shows a plot of this measure for the data set shown in panel (A) against the spot ratio for the corresponding mRNA in the pool comparison experiment (shown in panel $B$ ). The Spearman rank correlation coefficient for this data was $(r=0.6921, p<0.0001)$. (B) Reproduced with permission, RNA 13: $982-997$ @ 2007 by the RNA society. 
$1 \mathrm{~h}$ prior to collection of the RNA by centrifugation at $16,000 \mathrm{~g}$ in a cooled microcentrifuge. The pellet is washed once with $80 \%$ ethanol.

8. The mRNA is resuspended in $22 \mu \mathrm{l} \mathrm{H}_{2} \mathrm{O}$ and desalted using BioRad Micro Bio-Spin6 columns (Cat \# 732-6221) prior to any further enzymatic analyses.

\subsubsection{RNA analyses for quality control}

To ensure that the fractionation procedure results in pools of mRNA with defined poly $(A)$ tail lengths, we employ two quality control steps prior to microarray analyses. First, we monitor the adenylation state of the bulk RNA in each fraction by $3^{\prime} \alpha-\left[{ }^{32} \mathrm{P}\right]$ $\mathrm{pCp}$ end-labeling followed by RNase $\mathrm{T} 1$ and A digestion (See Fig. 2A). Second, we monitor the adenylation state of individual mRNAs by the LM-PAT assay (Fig. 2C), which is also used to verify the selection of candidate mRNAs from the PASTA data.

2.2.3.1. Bulk poly $(A)$ tail length analysis. For bulk poly(A) tail length analysis in a sample, we $3^{\prime}$ end-label with $\alpha-\left[{ }^{32} \mathrm{P}\right] \mathrm{pCp}$ and digest with RNAses A and T1, as previously described [23]. This results in radio-labelled poly $(\mathrm{A})$ tracts which can be separated by $16 \%$ Urea-PAGE and visualized by autoradiography. We prepare $\alpha$ $\left[{ }^{32} \mathrm{P}\right] \mathrm{pCp}$ in-house and thus give the method for this also.

1. Pre-prepare $\alpha-\left[{ }^{32} \mathrm{P}\right] \mathrm{pCp}$ by assembling for a total of $20 \mu \mathrm{l} ; 5 \mu \mathrm{l}$ $\mathrm{dH}_{2} 0 ; 2 \mu \mathrm{l}$ of $10 \times$ Polynucleotide Kinase buffer; $2 \mu \mathrm{l}$ of $3 \mathrm{mM} \mathrm{Cp}$ (Sigma-Aldrich Cat \# C-1133); $10 \mu \mathrm{l}-\left[{ }^{32} \mathrm{P}\right]-\mathrm{ATP}(3000 \mu \mathrm{Ci} /$ mmol Perkin Elmer Cat \# NEG502A500UC) $1 \mu \mathrm{l}$ T4 Polynucleotide Kinase (10 U/ $\mu$ l New England Biolabs Cat \# M020L). Incubate for $30 \mathrm{~min}$ at $37^{\circ} \mathrm{C}$ and heat inactivate at $70^{\circ} \mathrm{C}$ for $5 \mathrm{~min}$. Store at $-80^{\circ} \mathrm{C}$ if not using immediately.

2. For the $3^{\prime}$ end-labelling of RNA, a $30 \mu \mathrm{l}$ reaction volume is prepared containing the following: $1 \mu \mathrm{g}$ of total RNA or $90 \%$ of each elution fraction (up to $17.5 \mu \mathrm{l}$ ); $3 \mu \mathrm{l}$ of $10 \times$ ligase buffer (supplied with Promega T4 RNA ligase Cat \# M105A); $3 \mu$ DMSO (Sigma-Aldrich Cat \# D2650); $300 \mu \mathrm{g}$ BSA (we use the stock $100 \mu \mathrm{g} / \mathrm{ml}$ acetylated BSA supplied with restriction enzymes from New England Biolabs); $2.5 \mu \mathrm{l} \alpha-\left[{ }^{32} \mathrm{P}\right] \mathrm{pCp}$ as prepared above or (the equivalent amount from a commercial source); and $1 \mu \mathrm{l} \mathrm{T} 4$ RNA ligase (10 U/ $\mu$ l Promega Cat \# M105A). Incubate for $2 \mathrm{~h}$ at $37^{\circ} \mathrm{C}$.

3. To cleave everything but the poly(A) tract, the labeled RNAs are then subjected to simultaneous degradation by RNase $A$ (cleaves after $\mathrm{G}$ and $\mathrm{C}$ ) and RNase $\mathrm{T}_{1}$ (cleaves after $\mathrm{T}$ ) for $2 \mathrm{~h}$ at $37^{\circ} \mathrm{C}$. In a total reaction volume of $80 \mu \mathrm{l}$, combine the $30 \mu \mathrm{l}$ of labelled RNA; $40 \mu \mathrm{g}$ yeast tRNA (as 'ballast'); $80 \mathrm{U}$ RNase $\mathrm{T}_{1}$ (Roche Cat \# 10109495001) and $4 \mu \mathrm{g}$ RNase A (Roche Cat \# $109169)$, and $8 \mu \mathrm{l}$ of $10 \times$ digest buffer ( $100 \mathrm{mM}$ Tris $\mathrm{pH} 7.5$, and $3 \mathrm{M} \mathrm{NaCl}$ ).

4. Stop the reaction by addition of $20 \mu \mathrm{l}$ stop solution $(2 \mathrm{mg} / \mathrm{ml}$ proteinase $\mathrm{K}$ (Roche Cat \# 745723), $130 \mathrm{mM}$ EDTA and $2.5 \%$ SDS) for $30 \mathrm{~min}$ at $37^{\circ} \mathrm{C}$.

5. Phenol-chloroform extract once by addition of $100 \mu \mathrm{l}$ of a solution of 50\% acid phenol and 50\% chloroform:isoamylacohol $(24: 1, v / v)$. Vortex thoroughly and spin in a microcentrifuge at $16,000 \mathrm{~g}$ for $5 \mathrm{~min}$. Transfer the aqueous phase to a new $1.5 \mathrm{ml}$ microfuge tube containing $20 \mu$ g of yeast tRNA (Sigma-Aldrich Cat \# 10109495001) as carrier. Precipitate RNA by addition of $250 \mu \mathrm{l}$ absolute ethanol and incubation at $-80^{\circ} \mathrm{C}$ for at least $1 \mathrm{~h}$ or overnight. Wash the pellet once with $80 \%$ ethanol and resuspend in $20 \mu$ of $\mathrm{dH}_{2} \mathrm{O}$.

6. Pre-prepare a $16 \%$ polyacrylamide sequencing gel using the SequaGel sequencing System Kit (National Diagnostics EC840). Our large format electrophoresis system is $35 \mathrm{~cm}$ wide, $45 \mathrm{~cm}$ long, and the gel has a width of $0.2 \mathrm{~mm}$ (Owl S3S). The gel is run pre-run at $45^{\circ} \mathrm{C}$ (using a temperature probe connected to the Biorad Power PAC 3000) and 100 Watt for 30 min prior to loading of the RNA.

7. In new microfuge tubes combine $5 \mu \mathrm{l}$ RNA and $5 \mu \mathrm{l} 2 \mathrm{x}$ Formamide RNA loading dye. Heat to $80^{\circ} \mathrm{C}$ for 5 min immediately prior to loading. Load 4-6 $\mu \mathrm{l}$ per lane using disposable sequencing tips. The gel is run at the same parameters until the bromophenol blue dye has migrated $\sim 2 / 3$ rd down the gel. The gel is transferred onto Whatman paper and visualised by autoradiography or phosporimager analysis using a FLA-5100 Fluorescence imager and MultiGauge software (Fuji, Tokyo, Japan).

2.2.3.2. Ligation-Mediated Poly(A)-Test (LM-PAT). The sensitive LMPAT assay $[18,24,25]$ can in many situations replace the benchmark combination of oligonucleotide-mediated RNAse $\mathrm{H}$ cleavage of the mRNA, followed by high resolution northern blotting for the $3^{\prime}$ cleavage fragment [26]. Briefly, RNA is first incubated with oligo $(\mathrm{dT})_{12-18}$ primers in the presence of T4-DNA ligase at $42{ }^{\circ} \mathrm{C}$, creating a poly(dT) copy of each mRNA's poly(A) tail within the sample. Addition of excess anchor- $(\mathrm{dT})_{12}$ primer and further incubation at $12{ }^{\circ} \mathrm{C}$ favours annealing of the anchor primer to unpaired $\operatorname{poly}(A)$ ends and ligation to the poly(dT) stretch. This assembly is then used to prime synthesis of first-strand cDNA by reverse transcription. PCR reactions with primers specific to the mRNA of choice and the anchor region generate LM-PAT products, which are visualised by agarose gel electrophoresis.

Due to the limited range of primer lengths in the oligo(dT) $)_{12-18}$ mixture some LM-PAT product 'laddering' is often visible. The use of a $(\mathrm{dT})_{12}$-Anchor primer further determines that the first 'rung' in the PCR product ladder represents all short tails that can accommodate a single $(\mathrm{dT})_{12}$ Anchor but not an additional oligo(dT) ${ }_{12-18}$ primer. To control for any bias due to incomplete saturation of poly(A) tails with oligo(dT) $)_{12-18}$ prior to cDNA synthesis or a drift towards shorter amplicons during PCR, we routinely include control reactions with total RNA from a deadenylase double mutant $\Delta$ pan2/ccr4-1 strain [27], in which all mRNAs possess long poly(A) tails $[28,29]$. We also recommend inclusion of a separate reaction, where cDNA synthesis is primed with an anchor- $(\mathrm{dT})_{12} \mathrm{VN}$ primer. PCR from this CDNA will generate a size marker for the shortest possible LM-PAT product for the mRNA being analysed (Fig. 2B inset). Finally, LM-PAT products can be cloned and sequenced to guard against mispriming and other PCR artefacts.

1. Dilute $1 \mu \mathrm{g}$ total RNA or $2-10 \%$ of a poly $(U)_{100}$ chromatography fraction to a total of $6 \mu \mathrm{l}$ with $\mathrm{dH}_{2} 0$ and add $1 \mu \mathrm{l}$ of a $1 / 40$ dilution of the stock oligo(dT) $)_{12-18}$ primers (GE Healthcare, Cat \# 27-7858-01; a $\sim 1 \mu \mathrm{g} / \mu \mathrm{l}$ stock is prepared by addition of $300 \mu \mathrm{l}$ to the microfuge tube containing $5 \mathrm{OD}_{260 \mathrm{~nm}}$ units and stored in small aliquots at $-80^{\circ} \mathrm{C}$ ). In practice, the dilution of the oligo(dT) 12-18 $_{18}$ primers linker is empirically determined and varies according to the activity of the T4 ligase and other parameters that are difficult to quantify. Readers are urged to refer also to Sallés et al. [30] and references therein for further discussion.

2. Incubate the RNA and primers at $65^{\circ} \mathrm{C}$ for 5 min to melt any secondary structure.

3. Meanwhile, prepare and pre-warm to $42^{\circ} \mathrm{C}$, a master-mix con-

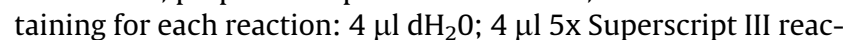
tion buffer; $2 \mu \mathrm{l} 0.1 \mathrm{M}$ DTT; $1 \mu \mathrm{l}$ dNTP mix (10 mM each, Roche Cat \# 1969064); $1 \mu \mathrm{l} 10$ mM ATP (Promega Cat \# P1132); $1 \mu \mathrm{l}$ T4-DNA ligase (New England Biolabs Cat \# M0202L); $0.5 \mu \mathrm{l}$ RNAseout (Invitrogen Cat \# 10777-019).

4. Flash spin down the denatured RNA, transfer to a $42{ }^{\circ} \mathrm{C}$ heat block and add $13 \mu \mathrm{l}$ pre-warmed master mix. Incubate for $30 \mathrm{~min}$. 
5. Add $1 \mu \mathrm{l}$ anchor-(dT) 12 primer GCGAGCTCCGCGGCCGCGTTT TTTTTTTTT $(100 \mu \mathrm{M}$ from Sigma-Genosys) and transfer to $12^{\circ} \mathrm{C}$ for $2 \mathrm{~h}$.

6. Return to $42^{\circ} \mathrm{C}$ for 2 min before addition of $1 \mu$ l Superscript III (Invitrogen Cat \# 18080044). Incubate at $42^{\circ} \mathrm{C}$ for $1 \mathrm{~h}$ and then increase temperature to $52^{\circ} \mathrm{C}$ for a further $1 \mathrm{~h}$. Inactivate the reverse transcriptase by incubation at $70^{\circ} \mathrm{C}$ for $10 \mathrm{~min}$.

7. Dilute reaction 5- to 10 -fold in $\mathrm{dH}_{2} \mathrm{O}$ and prepare $25 \mu \mathrm{l}$ PCR reactions using $5 \mu \mathrm{l}$ diluted PAT assay as template. Use standard PCR components and buffers supplied with the Fast-start Taq (Roche, Cat \# 12032937001). The gene-specific forward primer and the PAT assay primer are used at a concentration of $1 \mu \mathrm{M}$. Cycling conditions are: $2 \mathrm{~min}$ at $95^{\circ} \mathrm{C}$; then $30 \mathrm{~s}$ each at 95 , 60 and $72{ }^{\circ} \mathrm{C}$ for $25-35$ cycles (template-dependent); 2 min $72{ }^{\circ} \mathrm{C}$. The gene-specific primers for $S$. cerevisiae transcripts are generally designed at or near the stop codon to give a primer of 18-22 nucleotide length with a melting temperature of $>60^{\circ} \mathrm{C}$ and a PCR product size of between 100 and 300 base pairs. To design primers for LM-PAT assays on $S$. pombe and mammalian mRNAs where 3' UTRs tend to be longer, a suitable primer sequence is chosen within 200 base pairs from the cleavage and polyadenylation site. If unknown, the site can be narrowed down experimentally starting with a primer based around the sequence at the stop codon. In all cases, the amplified LM-PAT products encompass a region of the mRNA 3'UTR in addition to the stretch of $\operatorname{poly}(\mathrm{A})$ tail.

8. Run $1 / 3$ rd of the PCR product on $2 \%$ high-resolution agarose gels (Agarose 1000, Invitrogen Cat \# 10975-035) containing ethidium bromide for visualisation. For this, we use a FLA-5100 Fluorescence imager and MultiGauge software (Fuji, Tokyo, Japan).

9. To generate a size marker for the shortest possible LM-PAT product, cDNA is additionally synthesised with an anchor$(\mathrm{dT})_{12} \mathrm{VN}$ primer (5' GCGAGCTCCGCGGCCGCGTTTTTTTTTT TTVN; V: G,A, or C; N: any) to clamp the anchor to the 3'UTRpoly(A) junction. This reaction is carried out according to the product specifications for Superscript III, except that the reaction is assembled at $42^{\circ} \mathrm{C}$ and incubated at this temperature for one h, then at $52{ }^{\circ} \mathrm{C}$ for another hour. The PCR-product generated from this 'clamped' cDNA library is labelled 'TVN' in Fig $2 \mathrm{~B}$, inset.

\subsubsection{Microarray analyses}

The material eluted from the poly $(U)_{100}$ beads should be suitable for analysis on any single or dual-colour microarray, or indeed next-generation sequencing platform. Adjustment in experimental design and processing of the RNA samples will have to be made accordingly. We have previously used dual-colour spotted oligonucleotide microarrays, and our rather generic microarray and data analysis methods are detailed elsewhere $[18,19]$.

We implemented two experimental designs for the dual-colour microarray analysis of poly(U) eluates. The first uses five separate arrays to compare each eluate against reference mRNA (Fig. 1B). To obtain this reference, bound mRNA is eluted from beads in one batch at $45^{\circ} \mathrm{C}$. It may be necessary to combine each corresponding elution fraction from several parallel $\operatorname{poly}(U)$ chromatography runs at the scale detailed above, to achieve suitable amounts of labelled cDNAs. Standard data normalization means that a hypothetical mRNA representing the averaged elution pattern of all mRNAs would be assigned a spot ratio of 1 for each array in the series $[18,19]$. We then classify these high-resolution elution profile data employing a self-organising-map (SOM) algorithm and use the resulting matrix of profiles to select candidate mRNAs that deviate from the average elution pattern in an interpretable way (illustrated in Fig. 3A). In the second experimental design, we compare pooled low temperature fractions against a pool of high temperature eluates on a single microarray (Fig. 1C). One chromatography run at the scale detailed above should be sufficient to achieve suitable amounts of labelled cDNAs. Here, poly(A) tail status is represented by a single spot ratio, which is 1 for an mRNA with an average elution pattern. For this pool comparison we then empirically choose spot ratio cut-offs to generate mRNA candidate lists (Fig. 3B). Both approaches generate similar candidate lists, and in our published work we eventually settled on requiring an equivalent tail length assignment in both experimental approaches, yielding a combined 'PASTA-long' and 'PASTA-short' list [18]. As an alternative, our collaborators analysed high-resolution PASTA data by transforming ratios of each mRNA from the 5 elution fractions into one relative poly(A) tail length measure, which can be ranked ([19]; see legend to Fig. 3C for details). Provided the original data is of good quality, assignments of polyadenylation state should display good correlation between the different experimental designs (Fig. 3C).

\subsubsection{Further applications of the PASTA method}

An adaptation of the PASTA approach to other eukaryotic models is certainly feasible, but given the differences in the range of poly(A) tail lengths observed between organisms it will potentially require both, changes to the chromatographic separation step as well as the design of the microarray experiments and subsequent data analysis. In this regard, the reader is also referred to several publications that have approached the issue of $\operatorname{poly}(\mathrm{A})$ tail length control in different organisms using related approaches [31-33]. Finally, should future experimentation uphold and further strengthen the global positive correlation between poly(A) tail length and translation state observed thus far $[18,19]$, then measuring the functional state of mRNAs by the PASTA method might be considered a surrogate to the technically more demanding TSAA approach.

\section{Concluding remarks}

Our PASTA surveys of the S. cerevisiae and S. pombe transcriptomes have already uncovered a wide-spread coordination of mRNA polyadenylation state among cytotopically and functionally related mRNAs that exhibits evolutionary conservation and forms part of a multi-layered network of gene control. These studies were done on exponentially growing cells and could thus be expanded to survey other growth conditions or specific cell cycle stages. The power of yeast genetics could be deployed in combination with PASTA analysis to understand the molecular mechanisms by which cells implement and coordinate this type of gene control. Finally, after some methodological adjustments PASTA surveys could be carried out in more complex eukaryotic models and cellular contexts such as early embryonic development, in which tail length control is deemed particularly relevant. The common occurrence of multiple isoforms of cytoplasmic deadenylases and poly $(A)$ polymerases in complex eukaryotes suggest that gene regulation through control of $\operatorname{poly}(A)$ tail length is likely to be even more pervasive than currently anticipated.

\section{Acknowledgments}

We thank Jürg Bähler and Daniel Lackner for the productive collaboration on the PASTA analysis of the $S$. pombe transcriptome. Meghna Sobti is acknowledged for her critical reading of the manuscript. This work was supported by funds from the Victor Chang Cardiac Research Institute, the Australian Research Council, the National Health \& Medical Research Council of Australia, and the Sylvia \& Charles Viertel Charitable Foundation. 


\section{References}

[1] R. Parker, U. Sheth, Mol. Cell 25 (2007) 635-646.

[2] R. Parker, H. Song, Nat. Struct. Mol. Biol. 11 (2004) 121-127.

[3] N. Sonenberg, T.E. Dever, Curr. Opin. Struct. Biol. 13 (2003) 56-63.

[4] T. Preiss, M.W. Hentze, Bioessays 25 (2003) 1201-1211.

[5] N. Amrani, S. Ghosh, D.A. Mangus, A. Jacobson, Nature 453 (2008) 1276-1280.

[6] M.W. Hentze, F. Gebauer, T. Preiss, in: M.B. Mathews, N. Sonenberg, J.W.B. Hershey (Eds.), Translational Control in Biology and Medicine, Cold Spring Harbor Laboratory Press, Cold Spring Harbor, New York, 2007, pp. 269-295.

[7] D.T. Humphreys, B.J. Westman, D.I. Martin, T. Preiss, Proc. Natl. Acad. Sci. USA 102 (2005) 16961-16966.

[8] A.J. Giraldez, Y. Mishima, J. Rihel, R.J. Grocock, S. Van Dongen, K. Inoue, A.J. Enright, A.F. Schier, Science 312 (2006) 75-79.

[9] L. Wu, J. Fan, J.G. Belasco, Proc. Natl. Acad. Sci. USA 103 (2006) 4034-4039.

[10] I. Behm-Ansmant, J. Rehwinkel, T. Doerks, A. Stark, P. Bork, E. Izaurralde, Genes Dev. 20 (2006) 1885-1898.

[11] M. Wakiyama, K. Takimoto, O. Ohara, S. Yokoyama, Genes Dev. 21 (2007) 1857-1862.

[12] L.J. Colegrove-Otero, N. Minshall, N. Standart, Crit. Rev. Biochem. Mol. Biol. 40 (2005) 21-73.

[13] R. Mendez, J.D. Richter, Nat. Rev. Mol. Cell. Biol. 2 (2001) 521-529.

[14] R.L. Read, C.J. Norbury, J. Cell. Biochem. 87 (2002) 258-265.

[15] T.H. Beilharz, T. Preiss, Brief Funct. Genom. Proteom. 3 (2004) 103-111.

[16] J. Mata, S. Marguerat, J. Bahler, Trends Biochem. Sci. 30 (2005) 506-514

[17] T. Preiss, J. Baron-Benhamou, W. Ansorge, M.W. Hentze, Nat. Struct. Biol. 10 (2003) 1039-1047.
[18] T.H. Beilharz, T. Preiss, RNA 13 (2007) 982-997.

[19] D.H. Lackner, T.H. Beilharz, S. Marguerat, J. Mata, S. Watt, F. Schubert, T. Preiss, J. Bahler, Mol. Cell 26 (2007) 145-155.

[20] K. Kohrer, H. Domdey, Methods Enzymol. 194 (1991) 398-405.

21] R. Binder, J.A. Horowitz, J.P. Basilion, D.M. Koeller, R.D. Klausner, J.B. Harford, EMBO J. 13 (1994) 1969-1980.

[22] C.M. Palatnik, R.V. Storti, A. Jacobson, J. Mol. Biol. 128 (1979) 371-395.

[23] L. Minvielle-Sebastia, B. Winsor, N. Bonneaud, F. Lacroute, Mol. Cell. Biol. 11 (1991) 3075-3087.

[24] F.J. Sallés, S. Strickland, PCR Meth. Appl. 4 (1995) 317-321.

[25] J.L. Clancy, M. Nousch, D.T. Humphreys, B.J. Westman, T.H. Beilharz, T. Preiss Methods Enzymol. 431 (2007) 83-111.

[26] M.A. Steiger, R. Parker, Methods Enzymol. 351 (2002) 648-660.

[27] A. Traven, A. Hammet, N. Tenis, C.L. Denis, J. Heierhorst, Genetics 169 (2005) 65-75.

[28] M. Tucker, M.A. Valencia-Sanchez, R.R. Staples, J. Chen, C.L. Denis, R. Parker, Cell 104 (2001) 377-386.

[29] M. Tucker, R.R. Staples, M.A. Valencia-Sanchez, D. Muhlrad, R. Parker, EMBO J 21 (2002) 1427-1436.

[30] F.J. Salles, W.G. Richards, S. Strickland, Methods 17 (1999) 38-45.

[31] L. Du, J.D. Richter, RNA 11 (2005) 1340-1347.

[32] A. Graindorge, R. Thuret, N. Pollet, H.B. Osborne, Y. Audic, Nucleic Acids Res. 34 (2006) 986-995.

[33] H.A. Meijer, M. Bushell, K. Hill, T.W. Gant, A.E. Willis, P. Jones, C.H. de Moor, Nucleic Acids Res. 35 (2007) e132. 